\title{
Karekterisasi, Kinetika, dan Isoterm Adsorpsi Limbah Ampas Kelapa sebagai Adsorben Ion $\mathrm{Cu}$ (II)
}

\author{
Agusriyadin \\ Jurusan Kimia Fakultas Sains dan Teknologi USN Kolaka \\ Email : agusriyadin85@gmail.com
}

\begin{abstract}
Abstrak
Penelitian ini bertujuan untuk menguji kemampuan AK dan AKPM dalam mengadsorpsi ion Cu (II), pengaruh parameter adsorpsi dan mekanisme adsorpsi. AK dan AKP Madsorben dibuat dari residu ampas kelapa. Adsorben dikarakterisasi dengan FTIR, SEM dan EDS. Pengaruh parameter adsorpsi seperti pH awal, dosis adsorben, waktu kontak dan konsentrasi ion $\mathrm{Cu}$ (II) awal diperiksa untuk menentukan kondisi optimum serapan tembaga (II). Ion Cu (II) yang teradsorpsi diukur berdasarkan pada konsentrasi Ion Cu (II) sebelum dan sesudah adsorpsi menggunakan metode AAS. Hasil karakterisasi menunjukkan bahwa struktur pori dan gugus fungsi tersedia pada permukaan adsorben. Menurut percobaan efek $\mathrm{pH}$, kapasitas adsorpsi maksimum dicapai pada pH 7. Waktu kontak optimal dan konsentrasi tembaga awal (II) ditemukan masing-masing pada 120 menit dan $100 \mathrm{mg}$ L-1. Data eksperimental sesuai dengan model kinetik orde dua orde dua, dan Langmuir isoterm adsorpsi yang diperoleh paling sesuai dengan data adsorpsi. Kapasitas adsorpsi maksimum adsorben ditemukan menjadi 4,73 dan 6,46 mg g-1 pada kondisi optimal.
\end{abstract}

Kata kunci: Residu ampas kelapa, Adsorpsi, Ion Cu (II), Kapasitas adsorpsi

\section{PENDAHULUAN}

Metode adsorpsi merupakan salah satu teknik yang umum digunakan dalam pengolahan limbah yang memiliki beberapa kelebihan dibandingkan dengan metode lainnya seperti filtrasi, koagulasi, osmosis, ultrafiltrasi dan petukaran ion. Metode ini lebih mudah dioperasikan, dapat terdegradasi dan efektif menyerap logam berat (Bilal dkk., 2015). Prinsip adsorpsi didasarkan pada interaksi ion logam dengan gugus fungsional yang ada pada permukaan adsorben, melalui interaksi pembentukan kompleks dan biasanya terjadi pada permukaan padatan yang kaya akan gugus fungsional seperti $-\mathrm{OH},-\mathrm{NH},-\mathrm{SH}$ dan $-\mathrm{COOH}$ (Stumm dan Morgan, 1996). Pemilihan jenis adsorben selain ditinjau dari sisi efektifitas dan selektifitas dalam mengadsorpsi, juga diharapkan menelan biaya murah dan mudah dalam proses pembuatannya (Singha dan Das, 2013), seperti dengan memanfaatkan limbah pertanian.

Salah satu limbah pertanian lainnya yang belum dimanfaatkan secara luas adalah ampas kelapa. Ampas kelapa merupakan limbah pertanian yang diperoleh dari produksi pembuatan santan kelapa. Limbah ini biasanya digunakan sebagai pakan ternak atau hanya dibiarkan terurai begitu saja tanpa dimanfaatkan (Purawisastra dan Sahara, 2010). Analisis komponen kimia dari ampas kelapa menunjukkan adanya senyawa polisakarida seperti galaktomanan, mannan (polimer manosa), dan beberapa jenis polisakarida yang lain (Purawisastra, 2011). Senyawa-senyawa ini mengandung banyak gugus hidroksil $(-\mathrm{OH})$ pada struktur kimianya (Singh, dkk., 2009 dan Wang dan Chen, 2009), sehingga mempunyai kemampuan untuk mengikat kation logam (Volesky, 2007).

Tembaga merupakan salah satu logam berat yang cukup esensial dibutuhkan tubuh manusia. Akan tetapi konsumsi yang berlebihan dapat menurunkan fungsi kerja hati yang dapat mengakibatkan sakit kepala, muntah, mual, gangguan pernapasan, sakit perut, gagal hati, gagal ginjal dan pendarahan. Jumlah ion $\mathrm{Cu}^{2+}$ yang berlebih dalam sumber air bersih dan ekosistem perairan dapat merusak mekanisme kehidupan hewan air tawar dan menyebabkan mutagenesis pada manusia. Organisasi Kesehatan Dunia (WHO) menetapkan batas yang diperbolehkan $\mathrm{Cu}^{2+}$ dalam air minum adalah $1,5 \mathrm{mg} \mathrm{L}^{-1}$ (Bilal dkk., 2013), sedangkan United State

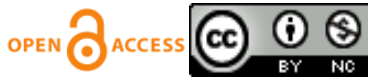


Environmental Protection Agency (USEPA) menetapkan batas yang diperbolehkan $\mathrm{Cu}^{2+}$ dalam limbah industri adalah1,3 $\mathrm{mg} \mathrm{L}^{-1}$ (Sud dkk., 2008).

Berdasarkan uraian yang telah dipaparkan di atas, maka penelitian ini mengkaji pemanfaatan ampas kelapa sebagai adsorben dalam mengurangi keberadaan ion logam berat $\mathrm{Cu}(\mathrm{II})$ dalam larutan. Beberapa parameter yang dikaji dalam penelitian ini mencakup karakterisasi adsorben menggunakan FTIR dan SEMEDS, faktor-faktor yang mempengaruhi adsorpsi seperti $\mathrm{pH}$, massa adsorben, waktu kontak dan konsentrasi awal ion logam serta model kinetika dan isotermal adsorpsinya.

\section{METODE PENELITIAN}

Bahan yang digunakan dalam penelitian ini adalah Ampas kelapa (limbah RM. Duta Minang) nheksana (Merck), Natrium Hidroksida ( $\mathrm{NaOH}$, Merck), Asam Klorida ( $\mathrm{HCl}$, Merck), Tembaga Nitrat $\left(\mathrm{Cu}\left(\mathrm{NO}_{3}\right)_{2} .3 \mathrm{H}_{2} \mathrm{O}\right.$, Merck), $\mathrm{Na}_{2} \mathrm{H}_{2}$ EDTA (merck), akuades dan akuabides. Alat yang digunakan dalam penelitian ini adalah Spektrofotometer Serapan Atom (Analytik Jena ContrAA 300 model CS 1.3.0), Spektrofotometer Infra Merah (Shimadzu model FTIR 8201 PC), SEM-EDS (JEOL JED-2300), peralatan gelas, alat refluks, pH meter (Metler Toledo dan PH-009(I)A), Indikator Universal, ayakan 60 mesh, kertas saring Whatman 42, desikator, neraca analitik (metter AE 200 dan Acis AD 300H), dan oven.

Limbah ampas kelapa dibersihkan dari kotoran yang menempel dan dicucidengan air bersih kemudian disaring dan diperas. Pencucian dilakukan berulang-ulang sampai didapatkan sisa air hasil penyaringan tidak berwarna atau jernih. Ampas kelapa selanjutnya dikeringkan menggunakan sinar matahari langsung. Ampas kelapa kering kemudian dihaluskan dan diayak dengan ayakan 60 mesh. Hasil ayakan ini diperoleh serbuk ampas kelapa (AK). Serbuk ampas kelapa kemudian diekstraksi sokhlet dengan menggunakan pelarut $\mathrm{n}$ heksana. Serbuk ampas kelapa yang telah diekstraksi kemudian dikeringkan dengan oven pada temperatur 70 ${ }^{\circ} \mathrm{C}$, kemudian diayak lagi dengan ayakan 60 mesh. Serbuk ampas kelapa ini kemudian disimpan dalam desiktor dan siap untuk digunakan (AKPM).

Serbuk ampas kelapa (AK) dan Serbuk ampas kelapa dengan penghilangan minyak (AKPM) yang akan digunakan sebagai adsorben dikarakterisasi dengan spektrofotometer Inframerah untuk mengetahui gugus-gugus fungsional dan SEM-EDS untuk mengamati morfologi permukaan dan komposisi unsur pada adsorben. Proses adsorpsi dilakukan dengan metode batch. Pengaruh $\mathrm{pH}$ ditentukan dengan menimbang 0,2 $\mathrm{g}$ adsorben (AK dan AKPM) dan dimasukkan ke dalam masing-masing wadah yang berisi $50 \mathrm{~mL}$ larutan $\mathrm{Cu}$ (II) $50 \mathrm{mg} \mathrm{L}^{-1}$ dengan variasi $\mathrm{pH}$ larutan 3 hingga 8 . $\mathrm{pH}$ larutan diatur dengan menggunakan campuran larutan $\mathrm{HCl}$ dan $\mathrm{NaOH}$. Campuran diaduk dengan stirrer selama 60 menit pada suhu kamar. Selanjutnya, setelah proses adsorpsi selesai, campuran adsorben dan adsorbat disaring dan kandungan logam dalam filtrat dianalisis dengan AAS. Kemudian ditentukan kapasitas adsorpsinya.

Banyaknya ion logam yang teradsorpsi pada adsorben (kapasitas adsorpsi) dihitung dengan menggunakan persamaan 1 (Hansen dkk., 2010) :

$\mathrm{q}_{\mathrm{e}}=\frac{\left(\mathrm{C}_{0}-\mathrm{C}_{\mathrm{e}}\right)}{\mathrm{m}} \times \mathrm{V}$

$\mathrm{q}_{\mathrm{e}} \quad=$ Kapasitas adsorpsi / jumlah ion logam yang teradsorpsi $\left(\mathrm{mg} \cdot \mathrm{g}^{-1}\right)$

$\mathrm{C}_{0} \quad=$ Konsentrasi awal ion logam (mg. $\left.\mathrm{L}^{-1}\right)$

$\mathrm{C}_{\mathrm{e}} \quad=$ Konsentrasi ion logam dalam larutan saat kesetimbangan (mg. $\left.\mathrm{L}^{-1}\right)$

$\mathrm{m} \quad=$ Massa adsorben $(\mathrm{g})$

$\mathrm{V} \quad=$ Volume larutan ion logam $(\mathrm{mL})$

Perlakuan pengaruh $\mathrm{pH}$ juga digunakan untuk menetukan parameter adsorpsi yang lain. Pengaruh massa adsorben dilakukan pada variasi massa 0,1- 0,6 g, pengaruh waktu kontak dilakukan pada variasi waktu 15-150 menit dan pengaruh konsentrasi awal ion $\mathrm{Cu}$ (II) dilakukan pada wariasi konsentrasi 10-100 mg L-1

\section{HASIL DAN PEMBAHASAN}




\subsection{Pembuatan Adsorben dari Limbah}

Penelitian ini diawali dengan preparasi limbah ampas kelapa sebagai bahan baku pembuatan adsorben. Preparasi yang dilakukan meliputi pencucian, pengeringan, penghalusan dan pengayakan serta penghilangan minyak. Ampas kelapa dibersihkan dari kotoran yang menempel dan dicuci dengan air bersih kemudian disaring dan diperas. Pencucian dilakukan berulang-ulang sampai didapatkan sisa air hasil penyaringan tidak berwarna atau jernih. Ampas kelapa kemudian diperas dengan menggunakan kain untuk mengurangi kandungan air. Ampas kelapa selanjutnya dikeringkan menggunakan sinar matahari langsung. Ampas kelapa yang sudah kering kemudian digerus dan diayak dengan ukuran 60 mesh. Pengayakan dimaksudkan untuk menyeragamkan atau menghomogenkan ukuran dan memperluas ukuran permukaan partikel ampas kelapa. Hasil pengayakan diperoleh serbuk ampas kelapa dan digunakan sebagai adsorben (AK).

Tahapan selanjutnya serbuk ampas kelapa kemudian diekstraksi sokhlet menggunakan pelarut nheksana. Tujuan perlakuan ini adalah untuk menghilangkan minyak dan pengotor lain yang menutupi pori serbuk ampas kelapa. Hasil analisis secara gravimetri menunjukkan kadar minyak yang diperoleh sebesar $24,60 \%$ (\% berat). Serbuk ampas kelapa yang telah di ekstrak kemudian dikeringkan dalam oven pada temperatur $70^{\circ} \mathrm{C}$ untuk menguapkan sisa pelarut n-heksana yang masih ada dalam serbuk ampas kelapa. Serbuk ampas kelapa kemudian diayak lagi dengan ukuran 60 mesh. Serbuk ampas kelapa ini kemudian disimpan dalam desikator dan siap untuk digunakan sebagai adsorben (AKPM).

\subsection{Karakterisasi Adsorben}

\subsubsection{Spektrofotometri FTIR}

Berdasarkan Gambar 1, pada spektra FTIR AK sebelum berinteraksi dengan ion Cu(II), pita serapan yang lebar dan kuat dapat dilihat pada bilangan gelombang $3448 \mathrm{~cm}^{-1}$ yang menunjukan vibrasi regangan O-H, mengindikasikan keberadaan ikatan dari gugus fungsi hidroksi pada struktur molekul ampas kelapa (Pavia dkk., 2009 dan Gorgievski dkk., 2013). Dua pita serapan pada bilangangelombang 2924 dan $2854 \mathrm{~cm}^{-}$ ${ }^{1}$ menunjukkanvibrasisimetri dan asimetridariregangan $\mathrm{C}-\mathrm{H}$ pada gugusalkil $\left(\mathrm{CH}_{2}\right)(\mathrm{Iqbal} \mathrm{dkk}$., 2009 dan Yan dkk., 2010). Bila spektrum FTIR dibandingkan sebelum dan sesudah adsorpsi ion logam $\mathrm{Cu}(\mathrm{II})$, teramati bahwa terjadi pergeseran pita serapan gugus fungsi hidroksil $(\mathrm{O}-\mathrm{H})$ dan $\mathrm{C}-\mathrm{O}$ sedangkan gugus $\mathrm{C}-\mathrm{H},-\mathrm{CH}_{2^{-}}$, $\mathrm{OH}$ dari $\mathrm{H}_{2} \mathrm{O}$ dan $\mathrm{C}-\mathrm{H}$ aromatik tidak mengalami pergeseran pita serapan. Pada adsorben $\mathrm{AK}$, pita serapan O$\mathrm{H}$ bergeserdari $3448 \mathrm{~cm}^{-1} \mathrm{ke} 3425 \mathrm{~cm}^{-1}$ dan pada AKPM, pita serapan O-H bergeserdari $3464 \mathrm{~cm}^{-1} \mathrm{ke} 3448 \mathrm{~cm}^{-}$ 1. Pitaserapan C-O pada adsorben AK, bergeserdari $1103 \mathrm{~cm}^{-1} \mathrm{ke} 1080 \mathrm{~cm}^{-1}$.

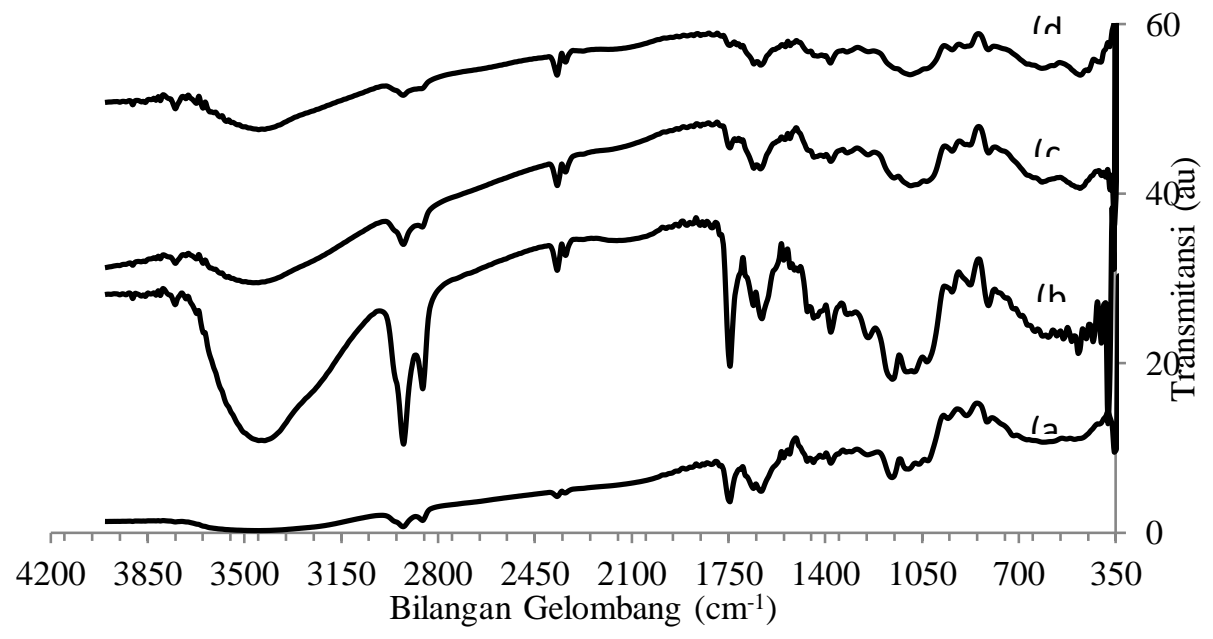

Gambar 1 Spektra IR (a) AK, (b) AK-Cu(II), (c) AKPM, dan(d) AKPM-Cu(II)

Menurut Gorgievski dkk. (2013) pergeseran serapan gugus fungsi yang karakteristik ini menunjukkan bahwa terjadi interaksi antara ion $\mathrm{Cu}$ (II) dengan gugus fungsi hidroksil $(\mathrm{OH})$ dan $\mathrm{C}-\mathrm{O}$. Hal ini disebabkan 
ketika terjadi interaksi antara gugus $\mathrm{OH}$ dan ion $\mathrm{Cu}(\mathrm{II})$ maka massa tereduksi $\mu$ menjadi lebih besar. Berdasarkan hukum Hooke $\bar{v}=\frac{1}{2 \pi \mathrm{c}} \sqrt{\frac{\mathrm{k}}{\mu}}$ semakin besar massa tereduksi $\mu$ maka nilai frekuensi/bilangan gelombang $\bar{v}$ menjadi lebih kecil (Barcelo, 2001). Secara umum, adsorben yang digunakan pada penelitian ini (AK dan AKPM) mengandung gugus hidroksil yang berperan penting dalam adsorpsi ion logam $\mathrm{Cu}(\mathrm{II})$.

\subsubsection{SEM-EDS}

Hasil analisis SEM menunjukkan bahwa adsorben AK dan AKPM sebelum interaksi mempunyai struktur permukaan yang berpori dan tidak beraturan. Selain itu permukaan kedua absorben memiliki morfologi dengan tekstur yang lekuk (Gambar 2a dan 2b). Setelah proses adsorpsi dilakukan, tekstur leluk tidak mengalami perubahan dan keberadaan pori pada permukaan AK dan AKPM tidak tampak. Gumpalan seperti buncis yang berlapis juga muncul permukaan adsorben. Selain itu interaksi AK dan AKPM dengan ion $\mathrm{Cu}(\mathrm{II})$ menyebabkan pembentukan bongkahan-bongkahan kecil pada permukaan adsorben (gambar2c dan 2d). Keadaan ini hampir sama bila dibandingkan dengan hasil SEM adsorpsi ion logam $\mathrm{Cu}$ (II) pada adsorben limbah tomat seperti Gambar II.6. Munculnya bongkahan-bongkahan kecil pada permukaan adsorben menunjukan adanya interaksi yang terjadi antara adsorben dengan ion $\mathrm{Cu}(\mathrm{II})$ (Yargic dkk, 2014).

Hasil analisis EDS pada ampas kelapa(AK) setelah interaksi dengan $\mathrm{Cu}(\mathrm{II})$ ditunjukkan oleh Gambar 3. Berdasarkan hasil analisis EDS, pada Gambar 3 keberadaan unsur karbon (C) dan oksigen (O) sebagai komponen utama galaktomanan menunjukkan intensitas yang cukup tinggi yang terdeteksi pada nilai energi 0,277 dan 0,525 keV. Nilai energi yang diperoleh sesuai dengan hasil penelitian Florido dkk. (2010) yang menggunakan limbah tangkai anggur sebagai adsorben.

Keberadaan ion $\mathrm{Cu}$ (II) juga dapat diamati pada spektrum EDS dari adsorben. Hasil interaksiadsorbendengan ion $\mathrm{Cu}$ (II) menunjukkan puncak dengan intensitas rendah yang teramati pada nilaienergi $8.040 \mathrm{keV}$ dengan komposisi sebesar 0,82\% (\% massa) atau 0,18 (\% atom).

Nilai energi yang diperoleh sesuai dengan hasil penelitian Lu dan Gibb (2008) yang menggunakan limbah biji padi sebagai adsorben ion logam $\mathrm{Cu}$ (II). Keberadaan ion $\mathrm{Cu}$ (II) pada permukaan adsorben setelah interaksi mengindikasikan bahwa terjadi ikatan antara ion $\mathrm{Cu}(\mathrm{II})$ dengan unsur yang ada pada permukaan adsorben.
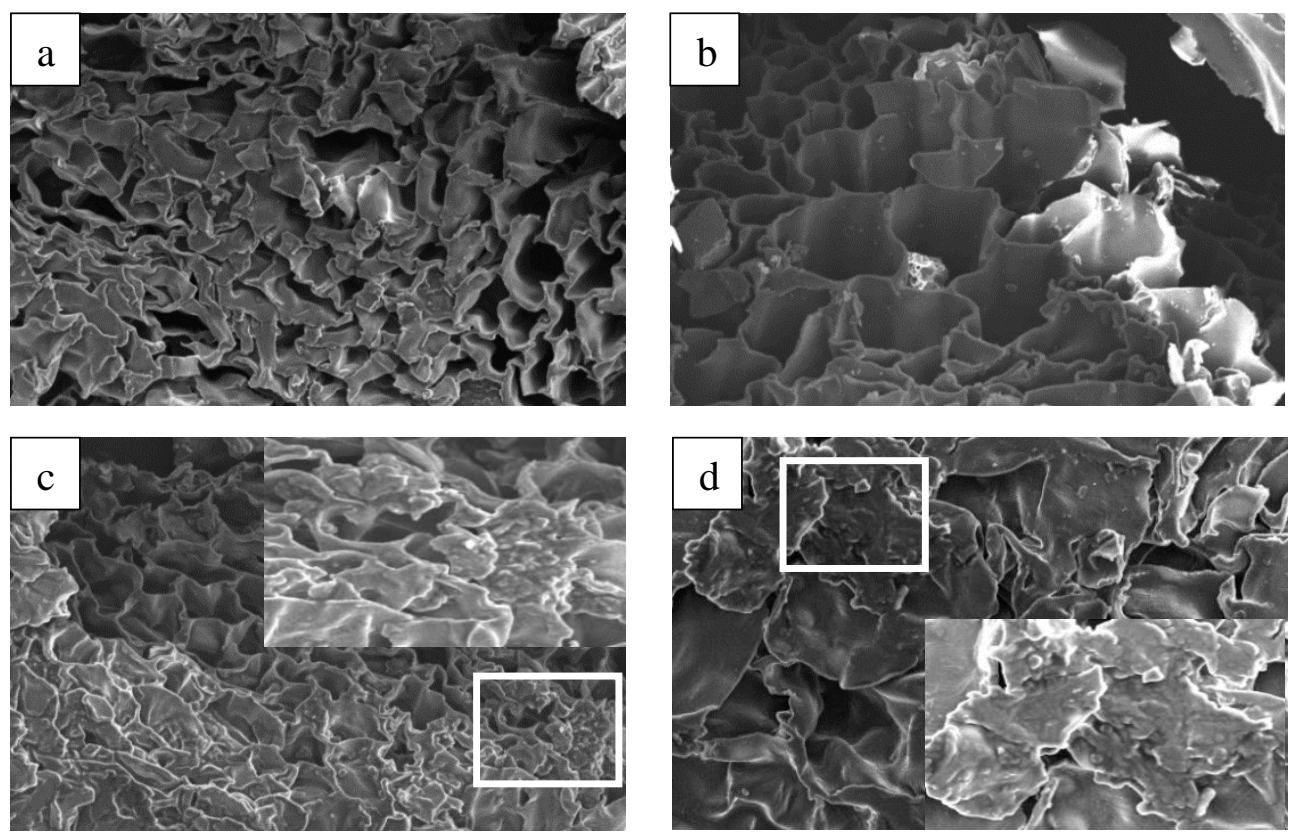

Gambar 2 Hasil SEM (a) AK, (b) AKPM, (c) AK-Cu(II) dan(d) AKPM-Cu(II)

\subsection{Kajian Adsorpsi}




\subsubsection{Pengaruh $\mathrm{pH}$}

Hasil penelitian pengaruh $\mathrm{pH}$ larutan terhadap kapasitas adsorpsi ion $\mathrm{Cu}(\mathrm{II})$ dapat dilihat pada Gambar 4. Gambar 4.a menunjukkan bahwa kapasitas adsorpsi ion $\mathrm{Cu}$ (II) makin meningkat seiring dengan peningkatan $\mathrm{pH}$ larutan dan mencapai nilai optimum pada $\mathrm{pH}$ tertentu, setelah itu mengalami penurunan kapasitas adsorpsi pada $\mathrm{pH}$ yang lebih tinggi. Menurut Powell dkk. (2007), perbedaan $\mathrm{pH}$ larutan menyebabkan ionCu(II) dalam air berada pada beberapa bentuk spesiasi. Pada $\mathrm{pH}$ rendah ion tembaga berada dalam bentuk $\mathrm{Cu}^{2+}$ dan pada saat yang sama, konsentrasi $\mathrm{H}^{+}$dalam larutan relative sangat besar. Banyaknya ion $\mathrm{H}^{+}$dalam larutan dapat menyebabkan terjadinya kompetisi dan tolakan antara $\mathrm{H}^{+}$dan ion $\mathrm{Cu}^{2+}$ untuk berikatan dengan situs aktif pada adsorben. Pada keadaan yang sama ( $\mathrm{pH}$ rendah) gugus fungsi adsorben berada dalam keadaan terprotonasi oleh $\mathrm{H}^{+}$sehingga adsorben lebih bermuatan positif (Farooq dkk., 2010). Hal ini menyebabkan tolakan elektrostatik antara ion logam dengan situs aktif adsorben, sehingga mengurangi kemampuan AK dan AKPM untuk menyerap ion logamCu(II).

Semakin tinggi $\mathrm{pH}$, konsentrasi ion $\mathrm{H}^{+}$dalam larutan semakin bekurang dan ion $\mathrm{Cu}$ (II) dalam air berada dalam bentuk $\mathrm{Cu}^{2+}, \mathrm{Cu}(\mathrm{OH})^{+}$dan $\mathrm{Cu}(\mathrm{OH})_{2 \text { (aq). }}$. Berkurangnya ion $\mathrm{H}+$ dalam larutan mengakibatkan kurangnya kompetisi antara $\mathrm{H}^{+}$dengan ion $\mathrm{Cu}^{2+}, \mathrm{Cu}(\mathrm{OH})^{+}$dan $\mathrm{Cu}(\mathrm{OH})_{2(\text { aq) }}$ sehingga banyak ion $\mathrm{Cu}$ (II) yang dapat terikat pada situs aktif adsorben. Larous dkk. (2005) menyatakan bahwa kapasitas maksimum meningkat pada $\mathrm{pH}$ asam dikarenakan adanya interksi $\mathrm{Cu}^{2+}, \mathrm{Cu}(\mathrm{OH})^{+}$dan $\mathrm{Cu}(\mathrm{OH})_{2(\text { (aq) }}$ dengan gugus fungsi yang ada pada adsorben dan pada $\mathrm{pH}$ 6, spesies ion $\mathrm{Cu}$ (II) dalam larutan $\mathrm{Cu}^{2+}$ berada dalam jumlah yang sangat kecil, sementara $\mathrm{Cu}(\mathrm{OH})^{+}$dan $\mathrm{Cu}(\mathrm{OH})_{2 \text { (aq) }}$ berada dalam jumlah yang besar. Li dkk. (2010) melaporkan ketika pH larutan meningkat, ion logam dalam larutan dapat berubah menjadi $\mathrm{MOH}^{+}$karena terhidrolisis dan bentuk ini mudah untuk diadsorpsi.

Pada keadaan yang sama ( $\mathrm{pH}$ tinggi) gugus aktif adsorben akan mengalami deprotonasi sehingga permukan adsorben menjadi bermuatan negatif (Farooq dkk., 2010), keadaan ini menyebabkan penyerapan ion logam semakin banyak. Li dkk. (2010), melaporkan bahwa kation logam kemungkinan dapat teradsorp lebih mudah pada permukaan negate fadsorben.

Kondisi $\mathrm{pH}$ optimum adsorpsi ion loganCu(II) olehadsorben AK dan AKPM tercapai pada pH 7, dengan kapasitas adsorpsi masing-masing 2,70 dan 3,45 $\mathrm{mg} \mathrm{g}^{-1}$. Jumlah ion logam yang berinteraksi dengan situs aktif adsorben mencapai jumlah maksimum, akibat berkurangnya jumlah $\mathrm{H}^{+}$dan masih minimnya keberadaan $\mathrm{OH}^{-}$yang dapat mengendapkan ion logam sebelum berinteraksi dengan adsorben (Weng dkk, 2014). Peningkatan kapasitas adsorpsi dari pH 3 sampai 7 dapat dihubungkan dengan interaksi yang terjadi antara gugus fungsi AK dan AKPM dengan ion $\mathrm{Cu}(\mathrm{II})$.

Li dkk. (2010) menerangkan bahwa kapasitas adsorpsi yang meningkat dapat dihubungkan dengan pertukaran ion antara kation logam dengan $\mathrm{H}^{+}$pada adsorben yang mengakibatkan penurunan nilai $\mathrm{pH}$. Dengan menggunakan grafik hubungan antara $\mathrm{pH}$ awal dan perubahan $\mathrm{pH}$ setelah adsorpsi, seperti yang ditunjukkan pada Gambar 4b, pH akhir larutan mengalami penurunan (keasaman lebih besar) bila dibandingkan dengan $\mathrm{pH}$ awal larutan. Keadaan ini menunjukkan jumlah $\mathrm{H}^{+}$dalam larutan lebih besar dari sebelumnya. Jumlah $\mathrm{H}^{+}$ yang dalam larutan dikarenakan pertukaran ion dapat meningkatkan jumlah $\mathrm{H}^{+}$dan mempengaruhi sistem $\mathrm{pH}$ dalam larutan.

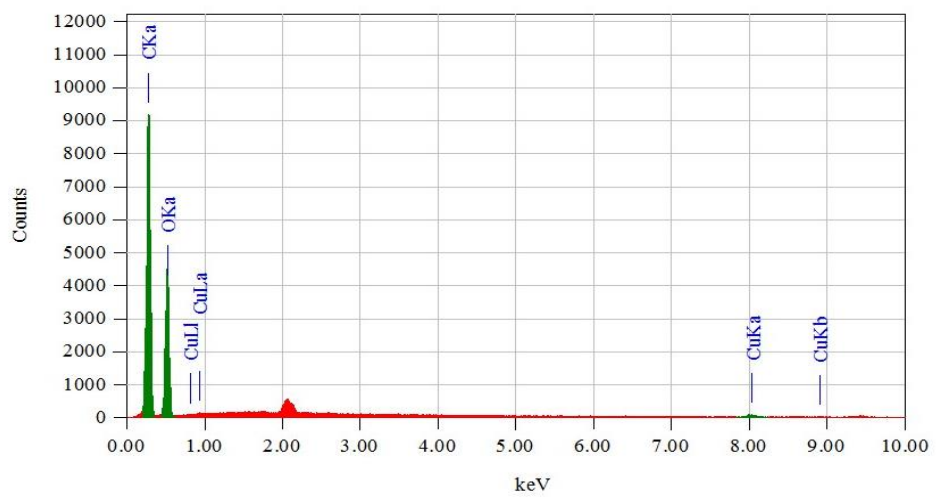

Gambar 3 Spektrum EDS dari AK setelahinteraksidenganCu(II) 
Model mekanisme pertukaran ion pada proses adsorpsi ion $\mathrm{Cu}(\mathrm{II})$ oleh adsorben AK dan AKPM dapat dilihat pada Gambar 5. Selain itu, dapat pula terjadi pembentukan ikatan hidrogen antara ion $\mathrm{Cu}$ (II) yang terhidrolisis oleh air dengan permukaan adsorben(Gambar 5). Kedua model mekanisme ini diadopsi dari mekanisme pertukaran ion yang diusulkan oleh Al-Ghouti dkk. (2010).
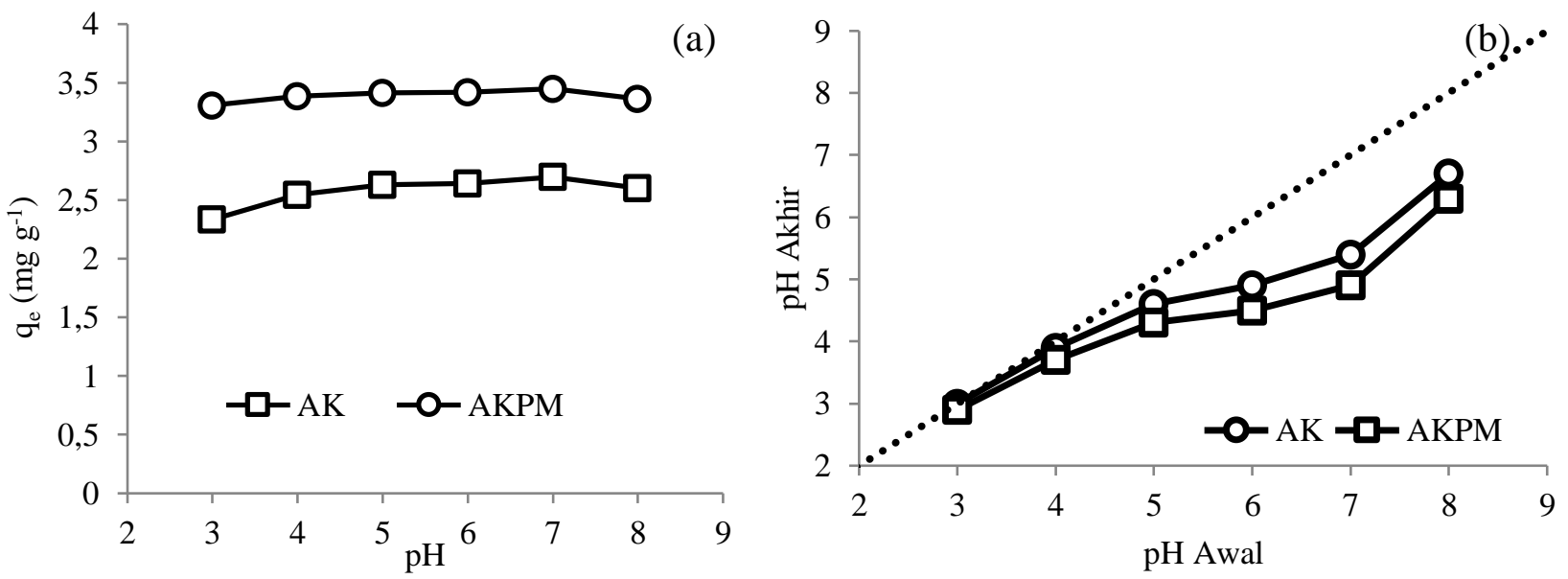

Gambar 4 Grafikpengaruh $\mathrm{pH}$ terhadap (a)kapasitas adsorpsi ; (b) perubahan $\mathrm{pH}$ setelah adsorpsi $\mathrm{Cu}(\mathrm{II})$ pada adsorben AK dan AKPM

$$
\begin{aligned}
& \left.\begin{array}{l}
2 \mathrm{R}-\mathrm{OH}+\mathrm{Cu}^{2+} \longrightarrow \\
\mathrm{R}-\mathrm{OH}+\mathrm{Cu}(\mathrm{OH})^{+} \longrightarrow \mathrm{Cu}+2 \mathrm{H}^{+} \\
\longrightarrow \quad \mathrm{R}-\mathrm{O}-\mathrm{Cu}(\mathrm{OH})+\mathrm{H}^{+}
\end{array}\right\} \quad \begin{array}{l}
\text { Pertukaran Ion } \\
\longrightarrow
\end{array} \\
& \mathrm{R}-\mathrm{OH}+\mathrm{Cu}(\mathrm{OH})_{2} \longrightarrow \mathrm{R}-\mathrm{OH}^{---}(\mathrm{OH})_{2} \mathrm{Cu} \quad \text { Ikatan Hidrogen }
\end{aligned}
$$

Keterangan : $\mathrm{R}=$ Matriks permukaan adsorben

Gambar 5. Model mekanisme pertukaran ion dan ikatan hidrogen adsorpsi $\mathrm{Cu}^{2+}, \mathrm{Cu}(\mathrm{OH})^{+}$dan

$\mathrm{Cu}(\mathrm{OH})_{2}$ pada permukaan adsorben (Ahmed, 2011)

Setelah kondisi optimum, kenaikan $\mathrm{pH}$ larutan menimbulkan penurunan jumlah ionCu(II) yang teradsorpsi. Hal ini diakibatkan karena pada $\mathrm{pH}$ tinggi, keberadaan ion $\mathrm{OH}^{-}$dalam larutan dapat menyebabkan terjadinya kompetisi antara $\mathrm{OH}^{-}$dan situsaktif pada adsorben untuk berikatan dengan ion logam. Selainitu, pada $\mathrm{pH}$ yang semakin tinggi, dimungkinkan terbentuk endapan dari interaksi ion $\mathrm{Cu}$ (II) dengan $\mathrm{OH}^{-}$ membentuk $\mathrm{Cu}(\mathrm{OH})_{2(\mathrm{~s})}$ dan mengalami pengendapan sebelum terjadi interaksi dengan adsorben. Endapan hidroksida yang terbentuk sebelum interaksi dapat mengurangi jumlah ion logam yang dapat teradsorpsi sehingga dapat mengakibatkan menurunnya kapasitas adsorpsi. Keadaan ini hampir sama dengan penelitian Larous dkk. (2005), yang melaporkan bahwa penurunan adsorpsi pada pH basa disebabkan pembentukan kompleks hidroksida yang mengendap yang dapat mengurangi keberadaan ion $\mathrm{Cu}$ (II) dalam larutan.

\subsubsection{Pengaruhmassaadsorben}

Hasil Analisis pengaruh massa adsorben terhadap penyerapan logam $\mathrm{Cu}(\mathrm{II})$ ditunjukkan oleh gambar 6. Hasil analisis menunjukkan bahwa semakin besar massa adsorben yang digunakan, semakin besar pula penyerapan ion $\mathrm{Cu}(\mathrm{II})$ pada masing-masing adsorben, akan tetapi kapasitas adsorpsi mengalami penurunan. Penyerapan yang semakin besar seiring dengan bertambahnya massa adsorben yang digunakan dapat 
mengakibatkan situs aktif pada adsorben tersebut juga akan bertambah. Keadaanini menyebabkan jumlah ion logam yang terserap makin banyak sehingga persenpenyerapan semakin besar (Jellalidkk., 2011).

Secara teoritis kapasitas adsorpsi dipengaruhi oleh massa adsorben dan nilai kapasitas adsorpsi berbanding terbalik dengan massa adsorben (Hansen dkk., 2010). Dengan jumlah ionCu(II) yang tetap, menyebabkan jumlah ion logam yang terserap menjadi semakin kecil bila dibandingkan dengan banyaknya jumlah situs aktif yang ada dalam adsorben. Penurunan kapasitas adsorpsi yang disertai dengan peningkatan massa adsorben dikarenakan massa yang besar menyediakan banyak situs aktif adsorpsi dan selama proses adsorpsi banyak situs aktif yang tidak terpakai. Massa yang besar dapat menyebabkan penumpukan partikel adsorben yang dapat mengakibatkan penurunan luas permukaan total adsorben dan peningkatan jarak difusi logam pada permukaan adsorben (Li dkk., 2011). Penumpukan adsorben juga mengakibatkan banyak situs aktif yang terhalang dan tidak dapat berinteraksi bebasdengan ion $\mathrm{Cu}(\mathrm{II})$.

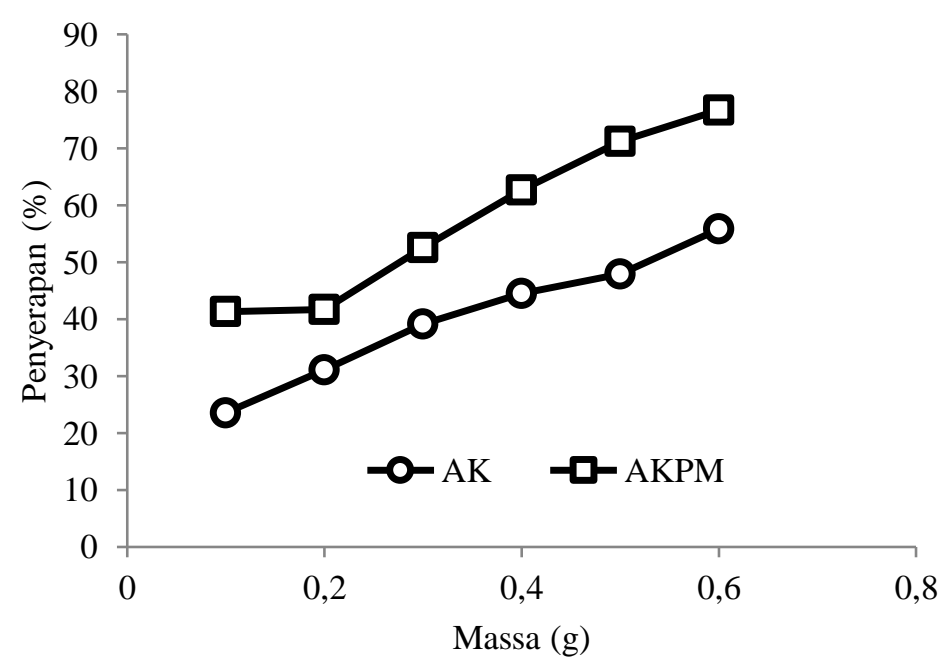

Gambar 6 Grafik pengaruh massa adsorben terhadap penyerapan $\mathrm{Cu}(\mathrm{II})$ pada adsorben AK dan AKPM

Selain itu adanya kemungkinan ion logam terhidrasi oleh molekul air dalam larutan menyebabkan ukuran ion logam menjadi lebih besar dan sukar berinteraksi dengan situs aktif adsorben.

\subsubsection{Pengaruh waktu kontak}

Hasil Analisis pengaruh waktu kontak terhadap kapasitas adsorpsi ion $\mathrm{Cu}(\mathrm{II})$ dapat dilihat pada Gambar 7. Gambar7. memperlihatkan bahwa secara umum seiring bertambahnya waktu kontak, terjadi peningkatan ion logam yang teradsorpsi pada masing-masing adsorben hingga waktu tertentu kemudian cenderung konstan.

Narsito dkk. (2004) menerangkan pola kinetika adsorpsi pada permukaan adsorben berlangsung dalam dua tahap, tahap cepat dan lambat kemudian mencapai kesetimbangan. Pola ini dapat terjadi bila laju adsorben dan adsorbat sama-sama dominan. Tahap pertama menunjukkan pola adsorpsi cepat pada menit-menit awal adsorpsi, ditandai dengan tingginya kapasitas adsorpsi pada menit ke-15(Gambar 7). Tingginya jumlah ion logam teradsorpsi pada tahap awal dari proses adsorpsi ini dikarenakan banyaknya jumlah situs aktif yang tersedia dan terbuka pada permukaan adsorben. Semakin situs aktif ditempati oleh ion logam menyebabkan tidak ada perbedaan kecepatan adsorpsi. Tahap kedua ditunjukkan dengan pola lambat sampai keseimbangan tercapai. Pola peningkatan adsorpsi menjadi lambat dan terus teramati hingga waktu adsorpsi selama 120 menit dan setelah itu jumlah yang teradsorpsi relative tidak meningkat lagi atau cenderung konstan. 


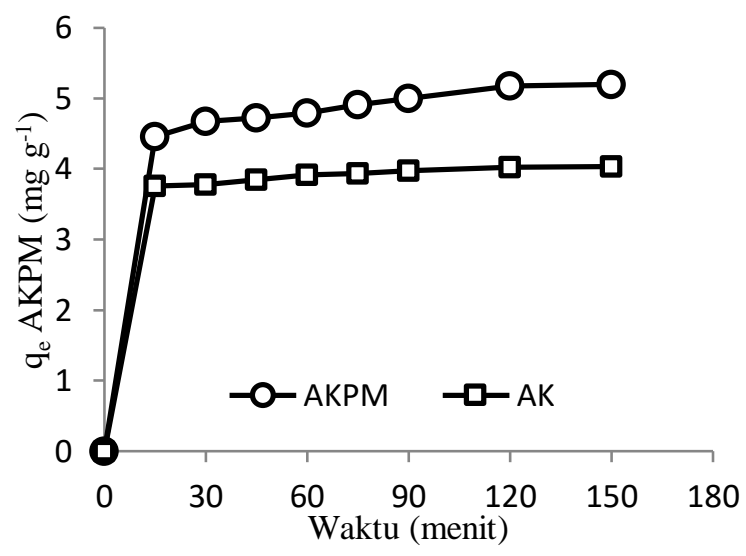

Gambar 7. Grafik pengaruh waktu kontak terhadap kapasitas adsorpsi Cu(II) pada adsorben AK dan AKPM

Hal ini dimungkinkan karena sebagian besar situs aktif adsorben telah mengikat ion $\mathrm{Cu}(\mathrm{II})$ sehingga perubahan waktu tidak merubah kapasitas adsorpsi menjadi lebih besar (Kamari dkk., 2014). Waktu optimum interaksi ion $\mathrm{Cu}$ (II) dengan adsorben AK dan AKPM tercapai pada menit ke-120 dengan kapasitas adsorpsi masingmasing 4,03 dan 5,20 $\mathrm{mg} \mathrm{g}^{-1}$. Tercapainya waktu optimum menunjukkan interaksi antara ion-ion logam dengan situs-situs aktif adsorben telah mencapai kesetimbangan (Castellan, 1982).

Kinetika adsorpsi logam $\mathrm{Cu}$ (II) pada AK dan AKPM di uji menggunakan model Kinetika reaksi orde nol, orde dua, orde tiga dan pseudo orde satu dan pseudo orde dua. Hasil yang diperoleh menunjukkan bahwa model kinetika reaksi pseudo orde dua merupakan model kinetika reaksi paling cocok dalam menggambarkan kinetika reaksi adsorpsi ion $\mathrm{Cu}(\mathrm{II})$ oleh $\mathrm{AK}$ dan AKPM dibandingkan model kinetika reaksi orde nol, orde dua, orde tiga dan pseudo orde satu (tabel 1).Pemilihan model kinetika reaksi pseudo orde dua di dasarkan pada tingginya linearitas grafik kinetika adsorpsi. Linearitas atau koefisien korelasi persamaan kinetika pseudo orde dua adsorpsi $\mathrm{Cu}$ (II) oleh AK dan AKPM adalah 0,999. Hasil inisesuai dengan Weng dkk. (2014), yang menunjukkan bahwa adsorpsi ion logam $\mathrm{Cu}$ (II) oleh limbah teh hitam lebih sesuai dengan model kinetika pseudo orde dua dibandingkan model kinetika yang lain.

Berdasarkan pertimbangan teoritis, reaksi dari ion logam divalen(M) mengikat satu situsaktif(B) dapat dijelaskan berdasarkan persamaan

$\mathrm{M}+\mathrm{B} \rightleftharpoons \mathrm{MB} \quad \mathrm{r}=\mathrm{k}[\mathrm{M}][\mathrm{B}]$

Persamaan ini menunjukkan bahwa tingkat penyerapan dan laju reaksi sebanding dengan konsentrasi logam dan jumlah situs aktif, dimana jika situs aktif dan ion logam sama-sama aktif maka keadaan ini cocok dengan bentuk $\left(\mathrm{q}_{\mathrm{e}}-\mathrm{q}_{\mathrm{t}}\right)^{2}$ pada model kinetika pseudo orde dua. Kecocokan model kinetika pseudo orde dua menunjukkan bahwa ikatan yang terjadi berlaku stoikiometri 1:1, dimana satulogam divalen mengikatsatu situs aktif adsorben (Lasheen dkk, 2012).

Tabel 1. Persamaan Kinetika Adsorpsi Cu(II) pada AK dan AKPM

\begin{tabular}{|l|l|c|c|}
\hline \multirow{2}{*}{ Model Kinetika } & \multirow{2}{*}{ Persamaan Linear } & \multicolumn{2}{c|}{$\mathrm{R}^{2}$} \\
\cline { 3 - 4 } & $\mathrm{C}=\mathrm{C}_{0}-\mathrm{kt}$ & $\mathrm{AK}-\mathrm{Cu}$ & $\mathrm{AKPM}-\mathrm{Cu}$ \\
\hline Ordenol & $\mathrm{ln} \mathrm{C}=\mathrm{ln} \mathrm{C}_{0}-\mathrm{kt}$ & 0,916 & 0,912 \\
\hline Ordesatu & $\frac{1}{\mathrm{C}}=\frac{1}{\mathrm{C}_{0}}+\mathrm{kt}$ & 0,908 & 0,939 \\
\hline Ordedua & $\frac{1}{\mathrm{C}^{2}}=\frac{1}{\mathrm{C}_{0}{ }^{2}}+2 \mathrm{kt}$ & 0,903 & 0,919 \\
\hline Ordetiga &
\end{tabular}




\begin{tabular}{|l|l|l|l|}
\hline Pseudo ordesatu & $\ln \left(\mathrm{q}_{\mathrm{e}}-\mathrm{q}_{\mathrm{t}}\right)=\ln \mathrm{q}_{\mathrm{e}}-\mathrm{kt}$ & 0,860 & 0,819 \\
\hline Pseudo ordedua & $\frac{\mathrm{t}}{\mathrm{q}_{\mathrm{t}}}=\frac{1}{\mathrm{k}_{2} \mathrm{q}_{\mathrm{e}}^{2}}+\frac{1}{\mathrm{q}_{\mathrm{e}}} \mathrm{t}$ & 0,999 & 0,999 \\
\hline
\end{tabular}

Model kinetika pseudo orde dua selanjutnya digunakan untuk menentukan nilai konstanta laju (k) adsorpsi dan kapasitas adsorpsi pada kesetimbangan $\left(\mathrm{q}_{\mathrm{e}}\right)$ ion $\mathrm{Cu}(\mathrm{II})$ oleh adsorben $\mathrm{AK}$ yang ditunjukkan pada Tabel 2. BerdasarkanTabel2nilai k adsorpsi ion Cu(II) oleh AK lebihbesardari AKPM.

Hal ini menunjukkan bahwa pada AK kecepatan adsorpsi $\mathrm{Cu}(\mathrm{II})$ mencapai kesetimbangan lebih cepat tercapai dari kecepatan adsorpsi Cu(II) oleh AKPM. Nilai kapasitas adsorpsi AK lebih kecil dibandingkan AKPM menunjukkan bahwa dengan massa adsorben yang sama, kemampuan menyerap AKPM lebih baik dari AK.

Tabel 2. Parameter kinetikaadsorpsiCu(II) pada AK dan AKPM

\begin{tabular}{|c|c|c|c|}
\hline \multirow{2}{*}{ Adsorben } & \multicolumn{3}{|c|}{ Pseudo ordeduaCu(II) } \\
\cline { 2 - 4 } & $\mathrm{k}_{2}\left(\mathrm{~g} \mathrm{mg}^{-1} \mathrm{~min}^{-1}\right)$ & $\mathrm{q}_{\mathrm{e}}\left(\mathrm{mg} \mathrm{g}^{-1}\right)$ & $\mathrm{R}^{2}$ \\
\hline $\mathrm{AK}$ & 0,103 & 4,09 & 0,999 \\
\hline $\mathrm{AKPM}$ & 0,037 & 5,35 & 0,999 \\
\hline
\end{tabular}

\subsubsection{Pengaruh konsentrasi awal ion logam}

Hasil Analisis pengaruh konsentrasi awal ion logam $\mathrm{Cu}(\mathrm{II})$ terhadap kapasitas adsorpsi diperlihatkan pada Gambar 8. Data hasil analisis menunjukkan bahwa pada konsentrasi rendah, sebagian besar ion $\mathrm{Cu}(\mathrm{II})$ teradsorp pada permukaan kedua adsorben. hal ini dikarenakan pada konsentrasi rendah jumlah ion logam yang ada dalam larutan jumlahnya sedikit, sehingga lebih mudah diadsorpsi oleh situs aktif adsorben akibatnya kapasitas adsorpsi dan persentase penyerapan menjadi maksimal.

Pada konsentrasi tinggi, jumlah ion logam yang teradsorpsi juga semakin besar, karena bertambahnya konsentrasi logam maka semakin banyak pula ion logam yang tersedia untuk berikatan dengan situs aktif. Akan tetapi, pada konsentrasi tinggi permukaan adsorben menjadi jenuh karena ion logam yang teradsorpsi semakin banyak akibatnya kapasitas adsorpsi mengalami kenaikan yang sedikit dan persen penyerapan menjadi berkurang.

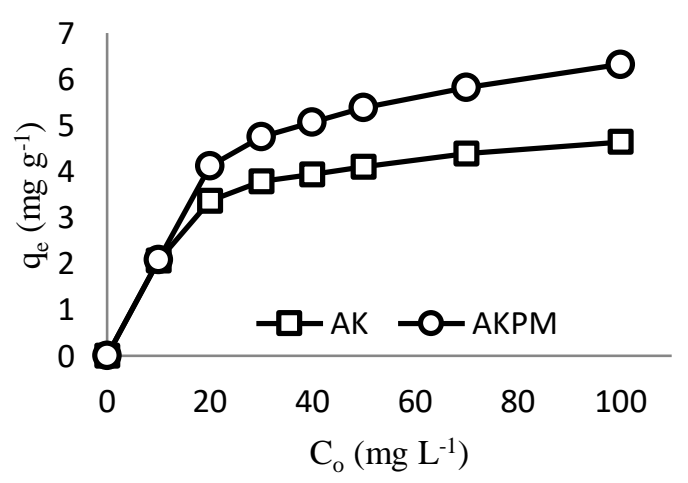

Gambar 8. Grafik pengaruh konsentrasi awal $\mathrm{Cu}(\mathrm{II})$ terhadap kapasitas adsorpsi pada adsorben AK dan AKPM

Hasil penelitian menunjukkan kapasitas adsorpsi Cu(II) pada AKPM lebih besardari AK, dengan nilai masingmasing 6,32 dan 4,63 $\mathrm{mg} \mathrm{g}^{-1}$. Hasil yang ditunjukkan Gambar 8. Menunjukkan bahwa jumlah ion logam teradsorpsi oleh adsorben meningkat ketika konsentrasi awal logam dinaikkan. Ketika konsentrasi awal $\mathrm{Cu}$ (II) dinaikkan dari 10 sampai $100 \mathrm{mg} \mathrm{L}^{-1}$, jumlah ion $\mathrm{Cu}$ (II) yang teradsorpsi pada adsorben $\mathrm{AK}$ mengalami 
peningkatan dari 2,07 menjadi 4,63 $\mathrm{mg} \mathrm{g}^{-1}$ dan pada keadaan yang sama kapasitas adsorpsi ion $\mathrm{Cu}$ (II) pada adsorben AKPM, meningkatdari 2,08 menjadi 6,32 $\mathrm{mg} \mathrm{g}^{-1}$.

Tingginya kapasitas adsorpsi pada konsentrasi awal ion $\mathrm{Cu}(\mathrm{II})$ yang besar dipengaruhi oleh dua faktor penting yaitu tingginya peluang tumbukan antara ion logam dan adsorben dan tingkat difusi yang tinggi ion logam kepada adsorben. Kedua hal ini akan meningkatkan driving force dan menurunkan resistansi transfer massa (Ozsoy dan Kumbur, 2006).

Kajian isoterm adsorpsi ion $\mathrm{Cu}$ (II) oleh adsorben AK dan AKPM menggunakan data dari kajian pengaruh konsentrasi awal ion $\mathrm{Cu}(\mathrm{II})$. Model isotermal yang digunakan pada penelitian ini adalah isoterm Langmuir, isoterm Freundlich dan isothermal Dubinin Kaganer Radush kevich (DKR). Melalui pendekatan model isoterm Langmuir, diketahui bahwa adsorpsi ion $\mathrm{Cu}$ (II) oleh AK dan AKPM memiliki linearitas yang baik. Nilai $\mathrm{R}^{2}$ keduanya adalah 0,997 dan 0,995 . Melalui pendekatan model isoterm Freundlich, nilai $\mathrm{R}^{2}$ masing-masing adsorben adalah 0,955 dan 0,879 sedangkan melalui pendekatan model isoterm DKR, nilai $\mathrm{R}^{2}$ kedua adsorben adalah 0,978 dan 0,91 (Tabel 3).

Model adsorpsi yang sesuai untuk adsorpsi ion $\mathrm{Cu}(\mathrm{II})$ oleh AK dan AKPM adalah model isoterm Langmuir, karena mempunyai linearitas yang lebih baik dibandingkan dua model isoterm yang lain. Tingginya koefisien korelasi regeresi linear $\left(\mathrm{R}^{2}\right)$ suatu model isoterm adsorpsi menunjukkan model isoterm tersebut paling sesuai untuk menggambarkan isoterm adsorpsi ion logam pada suatu adsorben (Tang dkk., 2014). Dengan demikian dapat dikatakan bahwa adsorpsi ion $\mathrm{Cu}$ (II) terjadi pada permukaan homogeny dari adsorben AK dan AKPM dan mengikuti pola monolayer (Kapur dan Mondal, 2014).

Tabel 3. Hasil AnalisisIsotermAdsorpsi

\begin{tabular}{|c|c|c|c|}
\hline \multirow{2}{*}{\multicolumn{2}{|c|}{ Parameter Isoterm }} & \multicolumn{2}{|c|}{$\mathrm{Cu}(\mathrm{II})$} \\
\hline & & AK & AKPM \\
\hline \multirow{5}{*}{ Langmuir } & Pers. linear & $\begin{array}{l}\mathrm{y}=0,2114 \mathrm{x}+ \\
0,7318\end{array}$ & $\begin{array}{l}\mathrm{y}=0,1548 \mathrm{x}+ \\
0,5899\end{array}$ \\
\hline & $\mathrm{R}^{2}$ & 0,997 & 0,995 \\
\hline & $\mathrm{q}_{\mathrm{m}}\left(\mathrm{mg} \mathrm{g}^{-1}\right)$ & 4,730 & 6,460 \\
\hline & $\mathrm{K}_{\mathrm{L}}\left(\mathrm{L} \mathrm{mg}^{-1}\right)$ & 0,289 & 0,262 \\
\hline & $\mathrm{E}\left(\mathrm{kJ} \mathrm{mol}^{-1}\right)$ & 24,322 & 24,084 \\
\hline \multirow{5}{*}{ Freundlich } & Pers. Linear & $\begin{array}{l}\mathrm{y}=0,1813 \mathrm{x}+ \\
0,3389\end{array}$ & $\begin{array}{l}\mathrm{y}=0,2311 \mathrm{x}+ \\
0,3965\end{array}$ \\
\hline & $\mathrm{R}^{2}$ & 0,955 & 0,879 \\
\hline & $\mathrm{n}$ & 5,516 & 4,327 \\
\hline & $\mathrm{K}_{\mathrm{F}}\left(\mathrm{L} \mathrm{mg}^{-1}\right)$ & 2,182 & 2,492 \\
\hline & $\mathrm{E}\left(\mathrm{kJ} \mathrm{mol}^{-1}\right)$ & 29,3323 & 29,6609 \\
\hline \multirow{5}{*}{$\begin{array}{l}\text { DKR } \\
\text { (DubininKaganerRadushkevich) }\end{array}$} & Pers. Linear & $\begin{array}{l}y=-2 \times 10^{-9} \times- \\
9,0441\end{array}$ & $\begin{array}{l}y=-2 \times 10^{-9} x- \\
8,5735\end{array}$ \\
\hline & $\mathrm{R}^{2}$ & 0,978 & 0,910 \\
\hline & $\mathrm{X}_{\mathrm{m}}\left(\mathrm{mol} \mathrm{g}^{-1}\right)$ & $1,181 \times 10^{-4}$ & $1,891 \times 10^{-4}$ \\
\hline & $\beta\left(\mathrm{mol}^{2} \mathrm{~J}^{-2}\right)$ & $-2 \times 10^{-9}$ & $-2 \times 10^{-9}$ \\
\hline & $\mathrm{E}\left(\mathrm{kJ} \mathrm{mol}^{-1}\right)$ & 15,8 & 15,8 \\
\hline
\end{tabular}

Model isotermal Langmuir kemudian digunakan untuk menentukan tetapan kesetimbangan, kapasitas maksimum dan energy adsorpsi. Nilai ketiga parameter isotherm Langmuir ini dapat dilihat pada tabel 3. Nilai tetapan kesetimbangan $\left(\mathrm{K}_{\mathrm{L}}\right)$ untuk adsorpsi ion $\mathrm{Cu}(\mathrm{II})$ oleh AK dan AKPM masing-masing 0,289 dan 0,262 L $\mathrm{mg}^{-1}$ sedangkan kapasitas maksimum adsorpsi ion $\mathrm{Cu}(\mathrm{II})$ oleh kedua adsorben tersebut adalah 4,73 dan 6,46 $\mathrm{mg} \mathrm{g}^{-1}$. Hasil perhitungan besarnya energi adsorpsi diperoleh energi adsorpsi sebesar $24,322 \mathrm{~kJ} \mathrm{~mol}^{-1}$ untuk AK dan 24,084 $\mathrm{kJ} \mathrm{mol}^{-1}$ untuk AKPM. Menurut Adamson (1990), adsorpsi dapat diklasifikasikan berdasarkan 
besarnya energi adsorpsi. Jika energi lebih dari $20,9 \mathrm{~kJ} \mathrm{~mol}^{-1}$, adsorpsi termasuk kategori adsorpsi kimia, sedangkan jika energi kurang dari nilai itu termasuk adsorpsi fisika. Berdasarkan kisaran energi adsorpsi, nampak bahwa untuk adsorpsi ion $\mathrm{Cu}(\mathrm{II})$ oleh $\mathrm{AK}$ dan AKPM cenderung pada kategori adsorpsi kimia karena energi adsorpsi keduanya lebih dari $20,9 \mathrm{~kJ} \mathrm{~mol}^{-1}$, walaupun masih berada pada perbatasan adsorpsi fisika.

\section{KESIMPULAN}

Limbah ampas kelapa yang berupa sebuk berwarna putih dapat dijadikan sebagai adsorben karena mempunyai pori dan memiliki gugus aktif hidroksil $(\mathrm{OH})$ pada permukaannya. Kondisi optimum adsorpsi ion $\mathrm{Cu}$ (II) oleh AK dan AKPM berlangsung pada keadaan yang sama yaitu $\mathrm{pH} 7$, dengan waktu kontak dan konsentrasi awal ion $\mathrm{Cu}$ (II) 120 menit dan $100 \mathrm{mg} \mathrm{L}^{-1}$. Model kinetika adsorpsi mengikuti persamaan kinetika adsorpsi pseudo orde dua dengan nilai konstata laju k adsorben AK dan AKPM sebesar 0,1032 dan 0,0367 g $\mathrm{mg}^{-1} \mathrm{~min}^{-1}$. Model isoterm adsorpsi mengikuti model isoterm Langmuir dengan nilai $\mathrm{K}_{\mathrm{L}}$ dan energi adosrpsi sebesar 0,289 $\mathrm{L} \mathrm{mg}^{-1}$ dan 24,322 $\mathrm{kJ} \mathrm{mol}^{-1}$ untuk AK serta $0,262 \mathrm{~L} \mathrm{mg}^{-1}$ dan 24,084 kJ mol-1 untuk AKPM. Kapasitas adsorpsi ion logam $\mathrm{Cu}$ (II) oleh AK dan AKPM pada kondisi optimum adalah sebesar 4,73 dan 6,46 $\mathrm{mg} \mathrm{g}^{-1}$.

\section{DAFTAR PUSTAKA}

Adamson, A.W., 1990, Physical Chemistryof Surfaces, $6^{\text {th }}$ Ed.,John Wiley and Sons, Inc., New York.

Ahmed S.A., 2011, Batch and Fixed-Bed Column Techniques for Removal of $\mathrm{Cu}$ (II) and $\mathrm{Fe}(\mathrm{III})$ usingCarbohydrate Natural Polymer Modified Complexing AgentsCarbohydrate Polymers, 83, 14701478.

Al-Ghouti, M.A., Li J., Salamh Y., Al-Laqtah N., Walker G. and Ahmad M. N.M., 2010, Adsorption Mechanisms of Removing Heavy Metals and Dyes from AqueousSolution using Date Pits Solid Adsorbent, J. Hazard. Mater 176, 510-520.

Barcelo, D., 2001, Modern Fourier Transform Infrared Spectroscopy Vol.35, Wilson and Wilson's, Inc., New York.

Bilal, M., Shah, J.A., Ashfaq, T., Gardazi, S.M.H., Tahir, A.A., Pervez, A., Haroon, H. and Mahmood, Q., 2013, Waste Biomass Adsorbents for copper Removal from IndustrialWastewater, A Review,

Castellan, G.W., 1982, Phisical Chemistry, $3^{\text {rd }}$ Ed, General Graphic Services, New York.

Farooq U., Kozinski J.A., Khan M.A.and Athar M., 2010, Biosorption of Heavy Metal Ions using Wheat Based Biosorbents, A Review of The Recent Literature, Bioresour. Technol.,101, 5043-5053.

Florido A., Valderrama C., Arévalo J.A., Casas I., Martínez M.and Miralles N., 2010, Application of Two Sites Non-equilibrium Sorption Model for the Removal of $\mathrm{Cu}$ (II)onto Grape Stalk Wastes in a Fixed-bed Column,Chem. Eng. J., 156, 298-304.

Gorgievski M., Bozic D., Stankovic V., Strbac N. and Serbula S., 2013, Kinetics, Equilibrium and Mechanism of $\mathrm{Cu}^{2+}, \mathrm{Ni}^{2+}$ and $\mathrm{Zn}^{2+}$ IonsBiosorption using Wheat Straw, Ecol.Eng.,58, 113- 122.

Hansen, H.K., Arancibia, F. and Gutiérrez, C., 2010 Adsorption of Copper onto Agriculture Waste Materials, J. Hazard. Mater., 180, 442-448.

Iqbal, M., Saeed, A. and Zafar, S.I., 2009, FTIR Spectrophotometry, Kinetics and Adsorption Isotherms Modeling, IonExchange, and EDX Analysis for Understanding the Mechanism of $\mathrm{Cd}^{2+}$ andPb ${ }^{2+} \mathrm{Removal}$ by MangoPeel WasteJ. Hazard. Mater 164, 161-171.

Jellali S., Wahab M.A., Hassine R.B., Hamzaoui A.H.and Bousselmi L., 2011, Adsorption Characteristics of Phosphorus from Aqueous Solutions onto Phosphate Mine Wastes, Chem.Eng. J.169, 157-165.

Kamari A., Yusoff S.N.M., Abdullah F.and Putra W.P., 2014 Biosorptive Removal of Cu(II), Ni(II) and Pb(II) Ions from Aqueous Solutions using Coconut Dregs Residue: Adsorption and Characterisation Studies, J. Environ. Chem. Eng., 2, 1912-1919.

Kapur, M. and Mondal, M.K., 2014, Competitive Sorption of $\mathrm{Cu}(\mathrm{II})$ and $\mathrm{Ni}(\mathrm{II})$ Ions from Aqueous Solutions: Kinetics, Thermodynamics and Desorption Studies,J. Taiwan. Inst. Chem.Eng., 45., 1803-1813.

Larous, S., Meniai, A.H. and Lehocine, M.B., 2005, Experimental Study of The Removal of Copper from AqueousSolutions by Adsorption using Sawdust, Desalination, 185, 483-490.

Karekterisasi, Kinetika, dan Isoterm Adsorpsi Limbah Ampas Kelapa sebagai Adsorben Ion Cu(II) 
Lasheen, M.R., Ammar, N.S. and Ibrahim, H.S., 2012, Adsorption/Desorption of $\mathrm{Cd}(\mathrm{II}), \mathrm{Cu}(\mathrm{II})$ and $\mathrm{Pb}(\mathrm{II})$ using Chemically ModifiedOrange Peel: Equilibrium and Kinetic Studies, Solid. State. Sci. 14, 202-210.

Li, Y., Yue, Q. and Gao, B., 2010, Adsorption Kinetics and Desorption of $\mathrm{Cu}$ (II) and $\mathrm{Zn}$ (II) from AqueousSolutiononto HumicAcid, J. Hazard. Mater.,178, 455-461.

Li, Y., Xia B., Zhao Q., Liu, F., Zhang P., Du, Q., Wang, D., Li, D., Wang, Z. and Xia, Y., 2011, Removal of Copper Ions from Aqueous Solution by Calcium AlginateImmobilized Kaolin, J.Environ. Sci., 23(3) 404-411.

Lu, S., and Gibb, S.W., 2008, Copper Removal from Wastewater using Spent-Grain as Biosorbent, Bioresour. Technol., 99, 1509-1517.

Narsito, Nuryono dan Suyanta, 2004, KinetikaAdsorpsiZn(II) dan Cd(II) pada Silika Gel termodifikasi Hasil Pengolahan Abu SekamPadi, Laporan Hasil PenelitianIlmu Dasar, November 2004, Lembaga PenelitianUniversitas Gadjah Mada, Yogyakarta.

Ozsoy H.D. andKumbur H., 2006, Adsorption of Cu(II) Ions on CottonBoll, $\quad J$. Hazard. Mater., 136, 911916,doi:http://dx.doi.org/10.1016/j.jhaz- mat.2006.01.035. 16490303.

Pavia, D.L., Lampman, G.M., Kriz, G.S. and Vyvyan, J.R., 2009, Introduction to Spectroscopy, ${ }^{\text {th }}$ Ed., Brooks/Cole Cengage Learning, Washington.

Powell, K.J., Brown, P.L., Byrne, R.H., Gajda, T.,Hefter, G., Sjöberg, S.and Wanner, H., 2007, Chemical Speciation of EnvironmentallySignificant Metals with Inorganic Ligands, Pure Appl. Chem., 5(70), 895950.

Purawisastra, S. dan Sahara, E., 2010, Isolasi Ampas Kelapa Rumah Tangga dan Bungkil Industri Minyak Kelapa, Panel Gizi Makan, 1(33), 23-29.

Purawisastra, S., 2011, The Use Of Various Ashes For Galactomannan Compound Isolationfrom Coconut Dregs, Teknologi Pencegahan Pencemaran Industri., 4(1), 260-266.

Singha, B. and Das, S.K., 2013 Adsorptive Removal of $\mathrm{Cu}$ (II) from Aqueous Solution and IndustrialEffluent using Natural/Agricultural WastesColloids Surf. B., 107., 97- 106.

Singh, V., Sethi, R.and Tiwari, A., 2009, Structure Elucidation and Properties of a Non-Ionic Galactomannan Derived fromThe Cassia pleurocarpaSeeds, Int. J. Biol.Macromol., 44, 9-13.

Stumm, W. and Morgan, J.J., 1996, Aquatic Chemistry, $3^{\text {rd }}$ Ed, John Wiley and Sons Inc., New York.

Sud, D.,Mahajan, G.and Kaur, M.P., 2008, Agricultural Waste Material as Potential Adsorbent for SequesteringHeavy Metal Ions from Aqueous Solutions, A Review, Bioresour. Technol., 99, 6017-6027.

Volesky, B., 2007,ReviewBiosorption and Me, Water Res., 41, 4017 - 4029.

Wang, J., and Chen, C., 2009, Biosorbents for Heavy Metals Removal and Their Future, Biotechnol. Adv., 27, 195-226.

Weng C.H., Lin Y.T., Hong D.Y., Sharma Y.C.,Chen S.C.and Tripathi K., 2014, Effective Removal of Copper Ions from Aqueous Solution using Basetreated Black Tea Waste, Ecol. Eng., 67,127-133.

Yan, C., Li, G., Xue, P., Wei, Q. and Li, Q., 2010, Competitive Effect of Cu(II) and Zn(II) on The Biosorption of Lead(II) byMyriophyllum spicatum, J. Hazard. Mater., 179, 721-728.

Yargic, A.S, Sahin, R.Z.Y., Ozbay, N. and Onal, E., 2014, Assessment of Toxic Copper(II) Biosorption from Aqueous Solution byChemically-Treated Tomato Waste (Solanum lycopersicum), J. lean. Pro., 1-8, doi: http://dx.doi.org/10.1016/j.jclepro.2014.05.087 